\title{
COLLAPSING ELECTORAL INTEGRITY IN MOZAMBIQUE
}

\author{
Joseph Hanlon
}

Joseph Hanlon is a visiting senior fellow in the Department of International Development, London School of Economics (LSE), London, and a visiting senior fellow in the Development Policy and Practice Group, Open University, Milton Keynes, UK

He has been writing about Mozambique since 1978 and has been editor of the Mozambique Political Process Bulletin since 1992, covering all the Mozambican multiparty elections

\begin{abstract}
Excessive secrecy has always compromised the integrity of Mozambique's elections. The National Elections Commission secretly changes results with no records kept nor any public notice that changes have been made. The official final results of the 2019 elections were changed three times by the Constitutional Council with no comment and identical document numbers. The political parties want a politicised electoral machine with party nominees to all electoral bodies, and integrity has steadily declined. By 2018-9 elections had become dominated by the ruling party, Frelimo, which was able to openly change the outcome of municipal elections and create 329430 ghost voters in the national elections. Civil society observers had become an important check on elections; but in 2019, independent observation was blocked in several provinces and the head of civil society observation in one province was assassinated by a police hit squad. The judiciary, which ordered a rerun in one town in the 2013 municipal elections, has become politicised and will no longer intervene. This paper is an empirical account of those events.
\end{abstract}

Keywords: Mozambique, elections, transparency, secrecy, fraud, elections commission

\section{INTRODUCTION}

An overwhelming desire to ensure peace propelled Mozambique's first multiparty elections in 1994. There was a remarkable turnout of $88 \%$ of registered voters. Frelimo candidate and incumbent president Joaquim Chissano won $53 \%$ of the vote. But Renamo's guerrilla leader-turned-presidential candidate 
Afonso Dhlakama won 34\% of the vote, showing that Renamo had real support, particularly in the centre of the country. Parliament was closer, with Frelimo gaining 129 seats, Renamo 112, and UD (the coalition União Democrática) winning 9. All parties accepted the result. There were 3000 international observers who gave high praise to the election. Both observation and subsequent detailed analysis showed very low levels of misconduct and irregularities.

After a ten-year liberation struggle, Mozambique achieved independence from Portugal in 1975 as a socialist one-party state under the single independence movement, Frelimo. In 1980 Ronald Reagan was elected United States president, and he sharply intensified the Cold War, which included proxy wars between East and West in several countries, including Mozambique. The US considered apartheid South Africa to be a bastion against communism and its socialist neighbours. Renamo had been created as a guerrilla force by white-ruled Rhodesia, and in 1980 was taken over by white-ruled South Africa to attack Mozambique. The ensuing war was brutal and destructive with major atrocities committed by Renamo; more than 1 million people died (7\% of the population), and there was massive destruction of schools, health posts and the commercial network. The war ended only in 1992 with the end of the Cold War. Part of the peace deal was multiparty elections, with Renamo as the main opposition party (Hanlon 1996, ch. 2).

The national desire for an end to war outweighed problems hidden in the electoral law and the deep distrust between the former warring parties, Frelimo and Renamo. But these have returned to overshadow all subsequent elections. Fraud and misconduct appear to have increased, and serious questions have been raised about the 1999 and 2019 elections. Those two elections set the scene for this paper.

The 1999 election was very close with Chissano beating Dhlakama by just 205000 votes. Former US President Jimmy Carter headed observer teams to Mozambique in 1999 and 2004 and he publicly questioned the 1999 outcome, noting that the National Elections Commission (Comissão Nacional de Eleições, CNE) secretly excluded more than 300000 votes. Furthermore, there were 241000 more votes in the presidential election than in the parliamentary election; there are separate ballot boxes for the two elections and no observer reported a voter putting a ballot paper in the presidential box but not in the parliamentary box. It also emerged that computer technicians had been sent to several provincial capitals to 'correct' the presidential results (Mozambique Political Process Bulletin (MPPB) January 2000 \& 29 December 2004). The head of computing for the 1994, 1999, and 2004 elections was also the head of the government data processing centre (Centro de Processamento de Dados, CPD), Orlando Comé, who apparently felt secure in that he had protection at the highest level. But Joaquim Chissano did 
not stand for president in 2004, and this protection melted away. On 7 December 2010 Comé was jailed for 12 years for using CPD funds and credit cards for travel, rent, and even spending in a casino (Mozambique News Reports $\mathcal{E}$ Clippings (MNRC) 18 December 2010), but not before a last strike. His software for the 2004 elections was ruled to be insecure and rushed changes meant it was delivered to provinces to start the count there three days after the election, and was still riddled with errors. In 2004 it was also impossible to know exactly how many people had registered, only that it was between 6.4 million and over 11 million (MPPB 29 December 2004).

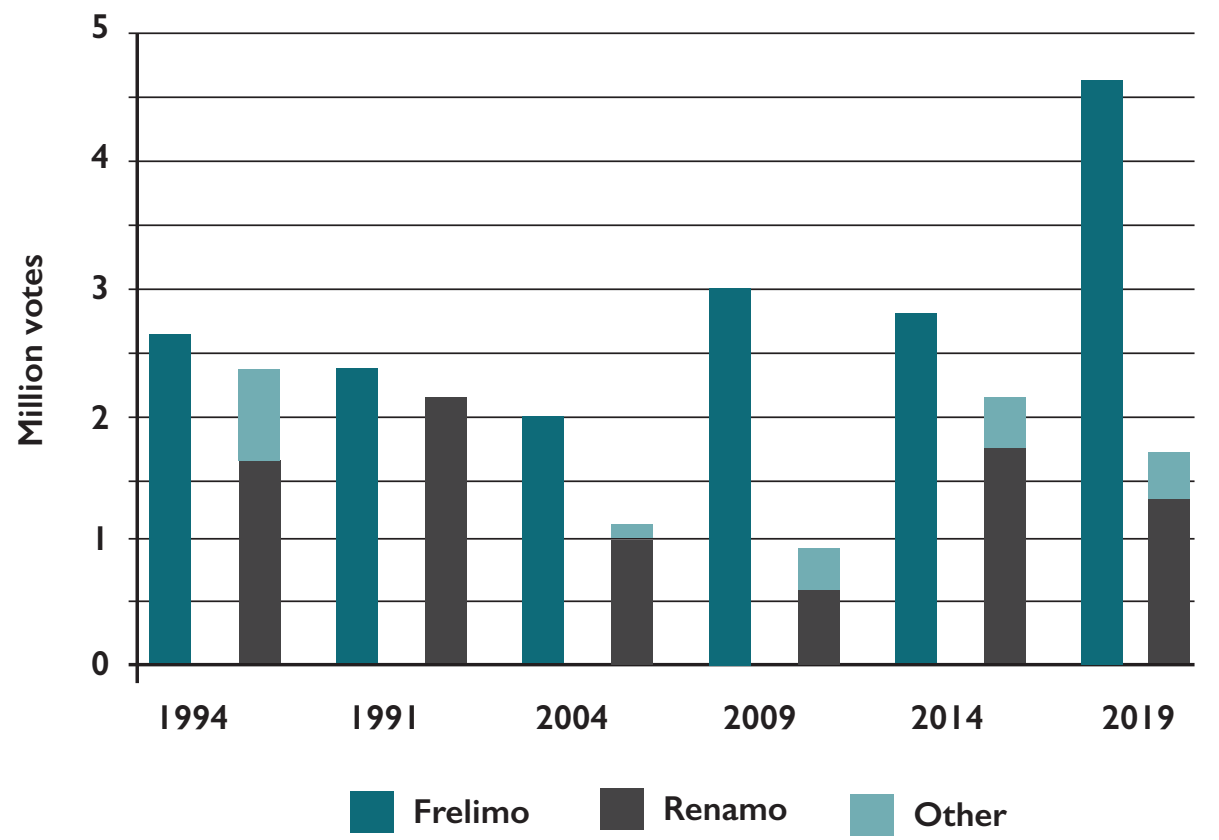

Figure 1: Presidential vote in six elections

Turnout in the next three national elections - 2004, 2009, and 2014 - was under half of registered voters (see Figure 1 above). Opposition votes fell to 25\% in 2009, largely attributed to a poor campaign by Renamo head Afonso Dhlakama who effectively said there was no point in voting for him because the election would be stolen, leading to significant numbers of opposition supporters not voting. There were indications of ballot box stuffing and spoiling of opposition ballot papers, but not enough to affect the outcome.

The next election in 2019 was expected to be very close. Problems started early. In the electoral registration in Gaza, which votes overwhelmingly for 
Frelimo, 329430 more people were registered than there were voting age adults in the province, according to the highly accurate 2017 population census. The National Statistics Institute (Instituto Nacional de Estatística, 2019) had sent this data to the CNE, and the respected head of the institute was dismissed by President Filipe Nyusi when he published his report to the CNE. The head of the census was later dismissed for defending the accuracy of the census (2019 General Elections - Mozambique Political Process Bulletin (GE-MPPB) 8 September 2019 \& 10 November 2019).

The head of civil society observation in Gaza was gunned down on 7 October by a police death squad. Nationally, more than 3000 civil society domestic observers were denied credentials. Implausibly, Frelimo won in every district in the country (MPPB 26 January 2020).

In the remainder of this paper, we analyse these events under the framework of electoral integrity. In its 2019 symposium 'Electoral Integrity in Africa' EISA does not define the concept. Kofi Annan (2012) defines electoral integrity as 'any election that is based on the democratic principles of universal suffrage and political equality as reflected in international standards and agreements, and is professional, impartial, and transparent in its preparation and administration throughout the electoral cycle'. This includes five areas:

- The rule of law to substantiate claims to human rights and electoral justice;

- professional, competent electoral management bodies with full independence to administer elections that are transparent and merit public confidence;

- institutions and norms of multiparty competition and division of power;

- no legal, administrative, political, economic, and social barriers to participation; and

- regulating political finance.

Pippa Norris (2015), introducing a symposium on electoral integrity, frames it in three areas:

- legal, i.e. no violations of domestic electoral laws, especially fraudulent manipulation of polling and tabulation;

- public sector management, i.e. technical capacity and no electoral maladministration;

- normative values, such as those of accountability, inclusiveness, and transparency. 
In this article, I follow Norris' framework, but also note the overlap between the three categories. I stress the inadequate structure and politicised nature of electoral administration and the core issue of transparency.

\section{DISTRUST AND WAR}

Deep distrust built during a decade of war, combined with both sides believing they had the support of the people and would win elections, led to the adoption of a strong president and winner-take-all form of government. Brazão Mazula, a respected former priest with Frelimo links, was named president of the first National Elections Commission (CNE) on 1 February 1994, less than nine months before the election date. A natural conciliator, he succeeded in making both sides work together. In the first parliament, the majority Frelimo bench was headed by Armando Guebuza, building an independent power base in his successful quest to become president. He thus created space between himself and then President Joaquim Chissano, and effectively made parliament the opposition to the government. This led initially to serious cooperation between the two parties, particularly at commission level.

But a 2020 study coordinated by UNU-Wider makes clear that there was never a real political settlement between Frelimo and Renamo, because there was no political or economic power-sharing. There were few senior military, economic or political posts for Renamo and there are even fewer now. 'There is no effective separation between party and state and big business' (Cruz, Ferreira, Flentø \& Tarp 2020).

Renamo head Afonso Dhlakama always recognised his weaker position during the 1990-92 Rome peace talks, the 1992-94 period with the UN presence and initial cooperation between the two sides, and then into 1994 elections. He often used boycotts as a way to gain concessions. Indeed, he boycotted the first day of the elections, 27 October 1994, and returned only after personal phone calls from the UN Security General and other international figures. Renamo swung between boycott, disruption, and conciliation in the first multi-party parliament, unsuccessfully boycotting parliamentary sessions to try and force Joaquim Chissano to name some Renamo ministers (MPPB February 1995). A law was agreed on the first local elections, in 33 municipalities; but then Renamo boycotted the municipal elections on 30 June 1998 (МРPB June 1997; September 1997; 21 July 1998.)

This deep distrust had two important consequences. Dhlakama and the Renamo leadership always believed that there were no senior neutral figures 
in Mozambique, and that it was impossible to create an independent, neutral election structure. Dhlakama ${ }^{1}$ in particular also believed that the only way to keep a check on Frelimo was to have as many Renamo people as possible inside the electoral system watching Frelimo.

Renamo has also, unusually in electoral democracies, been an armed party with a sizeable militia. Without leaving parliament, it boycotted the 2013 municipal elections and carried out military actions from April 2013 to April 2014 to successfully force changes to the electoral laws and the CNE (MNRC 8 April 2013, 12 February 2014, 7 April 2015 \& 8 May 2014; MPPB 9 April 2014). Renamo's return to war again in 2016 led to an agreement for elected provincial governors. These were small wars with relatively few casualties; Renamo closed the main north-south N1 road by shooting at traffic, while the army shelled the Renamo base in Gorongosa.

This led to huge instability in the electoral process with different electoral laws for the $\mathrm{CNE}$, for voter registration, separately for presidential, provincial and municipal elections, and for the role of the central state in provinces and municipalities. Some laws were changed for each election, often late and after political battles and boycotts. Some laws have been changed multiple times while others, such as that governing political parties, date back unchanged to 1991. The changes are inconsistent and there is sometimes disagreement between laws, notably on procedures and electoral calendars. The constitutional change for elected governors was only in July 2018 and the changes to six electoral laws only approved on 31 May 2019 for the national elections on 15 October (Leis 2/2019, $3 / 2019,4 / 2019,5 / 2019,6 / 2019,7 / 2019)$. Inconsistencies required ad hoc changes by the Constitutional Council and the CNE.

The outcome is not a well-written electoral code designed for smooth running, fair elections; instead, it is a jumble of inconsistent political concessions.

\section{CHANGING DEMOCRATIC AND ELECTORAL PROCCESSES}

The broad outline of Mozambique's electoral process has remained the same for all multi-party elections since 1994. But within that, there have been frequent changes.

The president of Mozambique is elected by an absolute majority $(50 \%+1)$ of Mozambican voters ${ }^{2}$. Below that are assemblies elected by proportional representation (party-list) systems. The 250 -seat national assembly or parliament

1 On 3 May 2018 Afonso Dhlakama died of a diabetes-related illness at the Renamo central military base on the Gorongosa mountain. He was replaced by Ossufo Momade, who stood as Renamo presidential candidate in 2019.

2 With a second round between the two candidates with most votes if none received $50 \%+1$. This has never been needed. 
(AR, Assembleia da República) is elected from lists of the 11 provinces (248 seats) and two seats from the diaspora. AR seats for the provinces are based on numbers of registered voters, but the repeatedly-changed law has maintained a mathematically incorrect way of assigning those seats ${ }^{3}$, often forcing the CNE to remove or add one seat for a province. This is done in secret as there is no legal provision to do so.

Provincial assemblies are elected from lists in the districts plus a provincewide list. The lowest level is only partly democratic: 53 municipalities have elected assemblies and mayors, while districts in more rural areas still have centrallyappointed administrations. The capital, Maputo City, has dual status as both province and municipality. It has an elected mayor and municipal assembly, and does not have a governor or provincial assembly, but the mayor effectively has the power of a governor.

The 10 provincial governors (not including Maputo City) and the 53 municipal mayors (including Maputo City) are elected in an unusual way - they head the lists ${ }^{4}$ that receive the most votes.

The electoral management structure is similar to that in many countries. There is a National Elections Commission (CNE, Comissão Nacional de Eleições) largely named by parliament. The actual running of elections is done by the Technical Secretariat for Electoral Administration (STAE, Secretariado Técnico de Administração Eleitoral), effectively part of the civil service. There are elections commissions and STAE at national, provincial and district/municipal level. Elections commissions are named for five years, while the STAE terms are unlimited. The CNE and national and provincial STAEs operate at all times; provincial elections commissions and district/municipal elections commissions and STAEs operate only in electoral periods. Elections commissions and STAEs have the same structures in both districts and municipalities, and are usually grouped together in the legislation.

Where the AR or an assembly makes nominations, for example for judges and CNE members, this is normally done by parties in proportion to seats in assemblies. Political battles led to repeated changes in the structure of the CNE and lower-level elections commissions and the hierarchic position and directors of STAE. As Figure 1 shows, the size of the CNE varied between 9 and 21 members, but always with a Frelimo majority. In an attempt to depoliticise the CNE in 2007 it was agreed that it should have members nominated by civil society organisations (CSOs), and that the president should be one of the CSO members. This failed

\footnotetext{
3 Because there cannot be half members of an assembly, proportional representation systems have various methods to allocate seats to parties. Mozambique uses the d'Hondt method. It should also use this to assign seats to provinces based on registration, but it does not.

4 The provincial governor is head of the province-wide list which receives the most votes.
} 
because civil society is also politicised and it was informally accepted that members would be appointed from party-aligned CSOs in proportion to seats in parliament, and that the president would come from a Frelimo-aligned CSO. This pattern is followed at provincial and municipal/district level, which ensured Frelimo has always dominated the electoral machinery. There is now a third, small party in parliament, the Mozambique Democratic Movement (Movimento Democrático de Moçambique, MDM), which is a break-away from Renamo, and which now has a few STAE and elections commission appointees.

\section{Table 1: Membership of National Elections Commission}

\begin{tabular}{|l|c|c|c|c|c|c|c|}
\hline Year & $\begin{array}{c}\text { Members } \\
- \text { total }\end{array}$ & President & Frelimo & Renamo & Government & $\begin{array}{c}\text { Other } \\
\text { CSO }\end{array}$ & Others \\
\hline 1993 & 21 & 1 & & 7 & 10 & & 3 \\
\hline 1997 & 9 & 1 & 4 & 3 & 1 & & \\
\hline 1999 & 17 & 1 & 8 & 6 & 2 & & \\
\hline 2002 & 19 & 1 & 10 & 8 & & & \\
\hline 2007 & 13 & 1 & 4 & 1 & & 7 & \\
\hline 2013 & 13 & 1 & 5 & 2 & & 2 & 3 \\
\hline 2014 & 17 & 1 & 5 & 4 & & 6 & \\
\hline
\end{tabular}

Source: author and Miguel de Brito, based on electoral laws

The civil service in the one-party state era was inevitably dominated by Frelimo, but for the first elections there was some attempt at neutrality - although as noted above, the head of computing was definitely a party appointment. From the election of Armando Guebuza as president in 2004, the civil service, including STAE, was more strongly politicised and expected to act in the interests of Frelimo. The response was initially to have CSO members of the election commission, which was subverted by the parties. Renamo moved to increase CNE control over STAE and extract it from civil service and ministerial control.

Renamo also demanded the right to appoint members of STAE, in effect to watch the government/Frelimo appointees. For the 2014 elections national STAE had 26 additional political appointments: two deputy directors-general (one Frelimo, one Renamo), six deputy department directors (three Frelimo, two Renamo, one MDM) and 18 other politically appointed staff (nine Frelimo, eight Renamo, one MDM). In 2014 there were more than 2200 party appointments to STAEs (more than 1100 Frelimo, 800 Renamo, and 300 MDM).

But the system failed. Renamo tended to use its posts as rewards for party loyalists and did not train them in what to look for. As a result, gross incompetence 
as well as blatant manipulation such as the Gaza registration inflation passed unnoticed.

In 2012 Sheik Abdul Carimo, then head of the joint CSO Electoral Observatory, said 'STAE and CNE are neither independent nor impartial bodies' (Carimo 2012). He was then named to the CNE as one of its Frelimo-aligned CSO nominees, and in 2013 became president of the CNE. Initial attempts to create some balance within the CNE failed, and the Frelimo take-over was complete by the 2018-9 elections.

\section{REGISTRATION AND POLLING STATIONS}

Voters must register anew for each pair of municipal and national elections. Registration is always quite high, because it is easier to register and obtain a plastic voter's card than an official identity card, and the voter's card is widely accepted as an ID card. Most registration is at the nearest school, and is recorded in books of 700 to 1000 people, the number being one of the things that changes for each election.

The polling station must be in the same place as registration and has one registration book. So polling stations are normally in classrooms in the school. A highly-praised part of the system is that each polling station is autonomous, run by polling station staff hired through an open public competition (more recently with some additional party nominees). All operations of the polling station are fully transparent and open to media, party monitors, and independent observers. Ballot papers are counted in the polling stations as soon as voting ends, and the results sheets (editais) are posted on the door of the polling station as soon as counting is complete. Results are then sent to the district/municipal elections commissions (CDEs) and CNE for compilation.

Polling station staff receive training and many are local teachers and other respected local figures. In the early elections observers often commented on their seriousness, patience and competence. At the lowest levels, there was a real pride in running fair elections.

As Frelimo influence increased and more cases of ballot-box stuffing and invalidating opposition ballot papers became clear, Renamo demanded the right to appoint polling station staff. Each party in parliament (Frelimo, Renamo, MDM) was then able to appoint one member for each polling station - more than 35000 paid political appointments. Again, the opposition did not train its nominees, many of whom who signed manifestly false editais; in some cases they apparently failed to notice the results sheet claim that turnout was over $100 \%$ of voters and clearly more than double the number who had voted. 


\section{TRANSPARENCY}

Transparency is the central pillar of democratic election systems. It is hard to cheat if everyone is watching. Polling stations are, officially, totally transparent. Posting the results at the polling station makes parallel vote tabulations (PVTs) possible and these are done by parties and observer groups. The law appears to make district, provincial and national tabulations open as well. But they are not. The electoral laws specify that certain parts of the process must be open, though they make no requirement that other parts be secret. But CNEs have always argued that all operations not required to be public are therefore secret; in particular, all work by STAE and all CNE meetings, minutes, etc. are secret. Thus, Mozambique's elections are unusually secret compared to other electoral democracies.

After the 2004 elections, former US President Jimmy Carter said that this was the 53rd election he had observed, and that the amount of corrections made to the results in 1999 exceeded anything in any similar election I have ever witnessed' (Carter 2004). The exclusion in 1999 of more than 600 polling stations that year was 'extraordinary. It is simply hard to believe that so many results sheets could not be used'. Exactly the same thing happened in 2004, with extensive corrections. STAE director general António Carrasco told international donors that 600 polling stations had been excluded - over 5\% of the total, and in secret. This was never said to any Mozambican audience or media and is nowhere reported in any public CNE or STAE document. No list was ever made available (MPPB 29 December 2004). Carter noted that the whole final tabulation process was done in secret and the lack of transparency meant there was no check on possible manipulation. He stressed that the level of access was unacceptable and said that in elections in other countries 'we have rarely been excluded from any significant part of the process' (ibid.).

Again in 2009 the Constitutional Council (CC) reported more than 300 polling stations were excluded by the $\mathrm{CNE}$ - in secret and never saying it had done so (Conselho Constitucional, Acórdão n 30/CC/2009 de 27 de Dezembro.) More bizarrely, the $\mathrm{CNE}$ excluded national parliamentary candidates from the third parliamentary party, MDM, on the basis that documents were incomplete or submitted late. MDM appealed to the CC. The CNE responded by submitting its mapa de controlo, a secret log of document submissions, which the CC accepted and rejected the appeal, although the document remained secret (Conselho Constitucional, Acórdão n²4/CC/2009 de 2 de Outubro). After the election the $\mathrm{CNE}$ announced that in the election for the provincial assembly, the small PDD party (Partido Para a Paz, Democracia e Desenvolvimento) had won $21 \%$ of the vote in Mocuba district, Zambézia, enough to gain one seat in the provincial assembly. When the CNE discovered that PDD had not stood in Mocuba and not submitted a list of candidates, it took away the seat. PDD appealed to the CC saying it was 
on the ballot paper and enough people had voted for it to win the seat. The CNE replied to the CC that the still secret mapa de controlo had major errors in it, leading the CNE to put PDD on the ballot paper by mistake (MPPB, 11 January 2010). As the 2009 mapa de controlo is still secret and no one outside the CNE and STAE has ever seen it there is no way MDM, PDD or anyone else could challenge it, but the $\mathrm{CC}$ accepted that the mapa de controlo was right with respect to MDM and wrong with respect to PDD.

What is astounding is that in this electoral democracy, the CC and CNE should agree that a mundane document such as a log of document submissions should be so secret that it can be used as evidence in appeals to the highest electoral court, yet neither the appellant nor anyone else may see and challenge the document. There is no public record of the most basic actions and decisions of the CNE.

Both sides have reasons to want secrecy. Dhlakama always felt that he had more power acting in secret and that it was easier to make deals. Before important CNE decisions, Renamo members had to use their mobile telephones to confirm their actions with Dhlakama. Information is power and he did not want it shared with the press and public.

On the Frelimo side, the secrecy often involved concealing things left to the last minute and then done sloppily. In 2004 electoral registers were never made public because they were still being corrected and cleaned two days before voting started. A complete list of polling stations and their register books was declared a 'state secret' but probably never existed. Last minute updating of the computer software and many errors in the data bases meant that corrections of results sheets and of the final results were done in a rushed and chaotic manner, and a full record of changes may never have existed.

Brazão Mazula, first CNE president and in 2004 head of the Electoral Observatory, the CSO observation coalition, commented: 'if you want to prepare a fraud, you start by disorganising the process' (MPPB 29 December 2004).

\section{COUNTING IN SECRET}

The electoral law has always specified a complex cascade count. Results sheets are sent by polling stations to municipal and district elections commissions (CDEs) where they are added up. The CDE produces results sheets which are then sent to the province where they are tabulated, and forwarded to the CNE. Thus, in law, each election commission simply adds up the totals of the level below. Furthermore, the tabulation process should be open to press, observers and party agents. Finally, the CNE submits the results for validation by the Constitutional Council, which serves as the highest electoral court. 
In practice, the count is not done that way. In reality, the tabulation at each level has been done by STAE, with decreasing involvement of the commissions. At national level STAE does an entirely separate count ignoring the cascade of provincial and district results.

The various electoral laws give specific tasks to STAE, for example organising polling stations. But through the 2013/4 elections, tabulations at municipal/ district, provincial and national level were specified as being done by the elections commissions. And, at each level, elections commissions publish official results.

Polling stations are required to send a copy of their results sheet (edital) to the CNE and, with those, national STAE has always done its own provisional count (apuramento provisório). In the 2013 municipal elections the official results published by the CNE and confirmed by the CC were different from those, also official, published by CDEs. CNE spokesman João Beirão conceded that the CNE did not even look at the city, district, and province results, and used the STAE apuramento provisório, so the CNE did not know that major changes had been made. CNE spokesman João Beirão said (2013): 'We know nothing about these changes. We are given the numbers by STAE. You have to speak to the director of STAE' (MPPB 26 December 2013).

In its ruling in 2014 the CC noted differences between the CNE reported results and those declared by the provincial elections commissions (CPEs). The CC made it clear that the CNE could not use the STAE apuramento provisório and must base its decisions on the provincial and city counts. 'The results made public by the provincial electoral commissions ... are the only data, allowed by law, for the general and national tabulation of votes' (Conselho Constitucional, Acórdão $n^{\circ}$ 21/CC/2014 de 29 de Dezembro).

So the law was changed to override the CC and officially give STAE the dominant role in the tabulation. This was done in the now confusing form of different changes to three different electoral laws. The law for the 2018 municipal elections says 'The National Electoral Commission is responsible for the general tabulation of local elections, and the material operations are carried out by the Technical Secretariat for Electoral Administration'. At municipality level, 'the District or Municipal Election Commission, through the Technical Secretariat for Electoral Administration, centralizes, polling station by polling station, the electoral results obtained at all polling stations' (Lei n ${ }^{\circ}$ 7/2018 de 3 de Agosto art $110,122,124)$.

But in what has been all too common, these changes were not carried forward into the national elections law (Lei $n^{\circ}$ 2/2019 de 31 de Maio) which meant that for the 2019 general elections, the CNE and other elections commissions were still expected to carry out the tabulations. However, one key change was made 
in the law for the 2019 national elections (Lei n 2/2019 de 31 de Maio art 149, 150, 151). An entirely new body was created, called a 'national tabulation assembly ... consisting of the plenary of the National Election Commission'. The only new task of this assembly is for tabulation verification to be done in secret. Party agents and observers are only allowed to attend this new assembly. The national tabulation assembly of 26 October 2019 was not actually a count, and simply consisted of showing the PowerPoint slides which had been approved at a closed CNE meeting the day before, by a 9-8 vote. That tabulation and compilation of results was done entirely by the STAE, as if the changes to the municipal elections law had been put into the national elections law. Then the election was approved by the Frelimo-aligned majority, with the president, Sheik Abdul Carimo, casting the key vote in favour.

\section{CHANGING PUBLISHED DOCUMENTS IN SECRET}

There was no way that political parties or observers could challenge or question the results, because they had no access to the data or the decisions involved in compiling the total. But the numbers done in secret by STAE and announced on 27 October 2020 were incorrect. As journalists began to work with the numbers, they quickly discovered that the published results included the registration in the diaspora but not their votes. The victorious President Filipe Nyusi had been denied 144934 votes and the percentage turnout was incorrect (GE-MPPB 27 October 2020).

The incorrect STAE numbers in the slide had been sent to the CC and were approved and published as Acórdão n²5/CC/2019 de 22 de Dezembro, nearly two months after press reports of the error, repeated on 23 December (GE-MPPB 23 December). In a remarkable display of transparency, on 2 January 2020 the CC replaced the document on its website with a new 'Acórdão n 25/CC/2019 de 22 de Dezembro'. It was pointed out that this corrected only some of the errors (GE-MPPB 5 January 2020) so a third 'Acórdão n 25/CC/2019 de 22 de Dezembro' was posted on 6 January. This still contained errors that were never corrected.

All versions of the ruling (acórdão) have a 14-page section highlighting the importance of transparency. But apparently this does not apply to the CC itself. No announcement was made of a change to the results; more seriously, there is nothing in the ruling that says it has been changed - all three versions are called 'Acórdão n 25/CC/2019, de 22 de Dezembro' with no indication of any change. ${ }^{5}$

5 The original 23 December 2019 is posted on http:/ / bit.ly/CCAc25-Orig. The second 2 January 2020 version, altered in secret, is on http: / / bit.ly / CCAc25-Corr-1. The third 6 January 2020 version, which in secret altered the second version which in secret altered the first version, is on http:/ / bit.ly / CCAc25Corr-2. 


\section{SECRECY TO COVER FRAUD}

The 2019 results fiasco shows how secrecy was used unsuccessfully to try to cover up slipshod administration. But it has also been used to cover fraud. In the 2018 municipal elections, STAE began to post its apuramento provisório on its website, which showed outcomes different to those in the official results. In Alto Molócuè, Zambézia province, and Monapo, Nampula province, the STAE apuramento provisório gave victory to Renamo but the CDE and CNE official results awarded the win to Frelimo. When that became obvious, STAE stopped posting the apuramento provisório. But posting results sheets (editais) on the door of the polling station makes it possible to do parallel counts, and a count done by journalists showed a Renamo victory in Moatize, Tete province, where the CDE and CNE awarded the victory to Frelimo. A civil society count in Alto Molócuè agreed with the STAE apuramento provisório which said Renamo had won. So in at least three municipalities, it appears the results were tampered with. In Marromeu, Sofala province, civil society observers reported that Renamo had a substantial lead when election officials ordered the police to stop the count.

Because the law does not specify transparency, key changes are often procedural and dependent on good will, which is often missing. The system of counting in polling stations avoids transporting ballot papers to counting centres - a key area of fraud in other countries. In 1998 STAE published a thick volume with the full results of the 1994 election by polling station (Mazula 1998). The data shows that in the now notorious district of Changara, in Tete province, some polling stations were claiming an impossible $95 \%$ or even $98 \%$ turnout, suggesting ballot box stuffing. This was not done in the disputed 1999 election. Data was released on a CD-ROM but only down to the level of voting centre; in a school there would be a polling station in each classroom, with the entire school called the voting centre. One of the issues of that election was that there were 241000 more votes for president than for parliament, while no one ever reported seeing a voter putting a ballot paper in the presidential box instead of in the parliamentary box. The less-detailed results made it impossible to pinpoint ballot box stuffing. For the 2003-4 elections a CD-ROM down to the level of polling station was widely distributed. For the 2008-9 elections a similar CD-ROM was produced but was only distributed to international election observer teams at the 2014 elections and not to Mozambicans, who received copies from observers. A CD-ROM for the 2013-4 elections was produced but never distributed, although it was leaked, and reveals increasing fraud. ${ }^{6}$ Without anything in law specifying transparency and publication, elections officials are free to supress or publish

6 The most detailed results available from all the elections are posted on http:/ / bit.ly / MozElData 
as they wish; voters and political parties have no rights to see basic information held by the electoral officials.

Subtle changes in procedures can also be used to cover up fraud. A problem in all elections has been that semi-literate voters are often not careful about putting the $X$ or fingerprint on the paper ballot paper, and their mark often spreads toward other candidates. The law says a vote is valid if the intention of the voter is clear. The count in the polling station is done in the presence of party agents who can protest, so there should be agreement on ballots labelled invalid (nulo). But local officials are often too strict in their rulings, and from 1994 all invalid ballot papers (sometimes 300000 or more) were sent to Maputo for reconsideration, where many were accepted. From 2004 this was done by CNE members (with Maputo CDE members to assist) and in public. It became clear in 2004 that some opposition votes had been intentionally invalidated; in the piles being reconsidered there would be a whole series of papers with a second candidate marked by an ink fingerprint in exactly the same place. It would have been easy to identify, because the fingerprint was clear and as this was a criminal offence, the small number of people involved in the polling station count could have been fingerprinted to identify the culprit. However, the procedure was that all invalid ballot papers from a district were put together in a single pile, making it hard to identify the polling station. No attempt was ever made to prosecute the culprits or make it easier to do so. By the 2014 elections Frelimo-nominated polling station staff members were under increasing local party pressure and during the requalification in Maputo a new version of this fraud was noticed. During the count in the polling station, ballot papers are sorted into piles on the floor. In the 2014 Maputo revalidation, handfuls of valid ballot papers for the opposition, with no extra mark, had been put into the piles of invalid votes sent to Maputo. It appeared that some polling station staff members wanted to look good for local Frelimo party leaders but knew the votes would eventually be counted at national level. For the 2019 election, the law was changed so the invalid ballots were reconsidered only by the district STAE, in secret. No record is available of local reconsiderations.

All versions of the electoral law require that certain electoral records are deposited in the national historic archive (Arquivo Histórico de Moçambique), (Lei $n^{\circ}$ 12/2014 de 23 de Abril art 273; Lei n²/2019 de 31 de Maio art 245) but this has never been done.

\section{POLITICS DETERMINES THE NEED FOR ELECTORAL INTERVENTION}

Frelimo is the party of liberation and the one-party state and so has become the predominant party of the multi-party era. But its dominance has had its highs and lows, as has Renamo, the party of Afonso Dhlakama. The 1994 election was the election to end war; it seems to have been largely fair and well run under 
difficult post-war conditions. Renamo boycotted the 1998 municipal elections, and did unexpectedly well in the 1999 national elections. The official results were close and serious questions have been raised about the outcome and the Frelimo victory. Frelimo's own analysis was that President Joaquim Chissano was being blamed by voters for growing corruption, and Frelimo did not select him as candidate for 2004 .

Frelimo's predominance was not seriously challenged in the 2003-4, 2008-9, and 2013-4 electoral cycles. Results were released of those elections down to the level of polling station. Combined with PVT and other data, it was clear that there was ballot box stuffing and invalidation of opposition ballot papers (detailed below). Substantial sloppiness was concealed by secrecy; some appears to have been intentional.

This period also saw the return to the one-party state and what Manning (2010) called 'a growing Frelimo monopoly on power at all levels' (Hanlon \& Smart 2008; Cruz et al. 2020). However, in the 2018-9 elections Frelimo came under more pressure due to public discontent over the $\$ 2 \mathrm{bn}$ secret debt and more general corruption, as well as growing inequality and the lack of development. Local party officials were under additional pressure to assure a Frelimo victory, and elections commissions (which all have a Frelimo majority under Mozambique's party-based system) became totally partisan. In the 2018 municipal elections the opposition officially won 9 of 53 municipalities including three important cities (Nampula, Quelimane and Beira) and parallel counts showed the opposition with the most votes in four others officially awarded to Frelimo. In 6 of the 53 municipalities no party has a majority in the municipal assembly. The opposition did far better than many commentators and Frelimo leaders expected.

Pressure on Frelimo members of STAE and elections commissions increased for the 2019 general elections. In the March-May electoral registration the total was significantly inflated in the Frelimo voting areas of Gaza and Cabo Delgado provinces and the diaspora, and suppressed in Renamo voting areas of Zambézia province. It is estimated that ghost voters, ballot box stuffing and invalidating opposition votes increased President Filipe Nyusi's majority by 557000 votes (МРPB 26 January 2020). Another major issue was the suppression of independent monitoring.

\section{OBSERVATION, INDEPENDENT MEDIA, DATA COMPARISONS, AND JUDGES}

The growing secrecy around STAE and CNE, the general decline in transparency, the failure of opposition parties to use the people they have inside STAE and 
$\mathrm{CNE}$, and the increasing fraud and misconduct in elections have put greater emphasis on outsiders watching those parts of the process they are allowed to see. Four groups are important: observers, independent journalists, a small group of numerate researchers who can compare public data and expose changes made by CNE and other misconduct, and a neutral judiciary.

For the 2014 elections there were 17202 polling stations. These were monitored by 10408 national observers and 526 international observers, as well as 1851 national journalists and 85 foreign journalists (Conselho Constitucional Acórdão n ${ }^{\circ}$ 21/CC/2014 de 29 de Dezembro).

From the first election, independent observation has been considered a key check on the integrity of the elections. Observers have total access to the processes on polling day and also report on the registration and campaign. International observation has been important but domestic observation has probably been more useful. For several elections there was a coalition called the Electoral Observatory which included religious groups. In 2019 CSO observation was coordinated by EISA Mozambique.

Domestic observation is probably most important psychologically, because it gives the message that polling station staff are being watched. But equally important has been the use of domestic observers to carry out a parallel vote tabulation (PVT) which is based on recording the posted results sheets (editais) at a statistically selected sample of polling stations. These have proved highly accurate. In 2014 the PVT covered $10.6 \%$ of polling stations and accurately predicted the $57 \%$ vote for Frelimo's Filipe Nyusi and $43 \%$ for the two opposition presidential candidates (MPPB 28 November 2014).

But there have always been problems with election officials who do not like being watched, and the biggest problems have repeatedly been Tete and Nampula (where the vote is close) and Gaza (where it is overwhelming Frelimo). In 2004 in Tete, Júlio Kalengo, the provincial sample count coordinator, was jailed for five days and not allowed to contact the Electoral Observatory (MPPB 29 December 2004). In 2014 in Tete observers were not allowed to collect data in $27 \%$ of polling stations. By law, CSO observers must be given credentials, but in 2014 in Nampula, $20 \%$ of PVT observers were never given credentials by the electoral authorities (MPPB 28 November 2014),

The 2019 election was much worse. On 7 October a police hit squad assassinated Anastácio Matavel, the coordinator of observation in Gaza, barely a week before the elections. EISA applied for observer credentials for 6955 observers, but only 4039 (58\%) were issued. In Zambézia only 24\% of credentials were issued and in Gaza only 27\%, followed by Tete (39\%) and Nampula (58\%) (МPPB 26 January 2020). 


\section{INDEPENDENT MEDIA}

Mozambique continues to have a vibrant and free independent media, including more than 100 community radio stations and many web-based local newspapers. In addition, the Mozambique Political Process Bulletin (MPPB) has covered all of Mozambique's multi-party elections. ${ }^{7}$ During this period the $M P P B$ developed an apparently unique journalist-observer system (Nuvunga \& Hanlon 2018; Hanlon \& Ahlbäck 2016). In 2019 there were 465 local correspondents (at least two in every district, most from community radios) and a team of ten in Maputo. Election editions of the $M P P B$ were published daily in key periods on Facebook, the web and e-mail, and twice weekly on community radio stations in seven local languages.

The effectiveness of this was shown as early as 2004, when observers and independent journalists found that more than 400000 people in more than 700 polling stations, mainly but not entirely in pro-Renamo areas, were unable to vote. This was due to polling stations which did not open, opened very late, were in the wrong place, or did not have the correct register book. The Electoral Observatory PVT showed that in $3.1 \%$ of polling stations in their survey, fewer than $5 \%$ of those registered actually voted, indicating that something very serious had gone wrong (MPPB 29 December 2004).

\section{USING DATA}

Mozambique's electoral process is highly unusual and totally non-transparent because STAE and the elections commissions can make any changes they wish without indicating these changes. There are circumstances where changes and decisions must be made - results sheets with arithmetic mistakes can sometimes be corrected, and it is reasonable to exclude polling stations with more than $100 \%$ turnout. But there is no indication that any record of changes exists. There is no audit trail which would make it possible to reconstruct what has been done. Indeed, at least in 2019, STAE only presented the final electoral results to the CNE for approval, with no explanation of the changes made.

Although the tabulation and compilation of the results is done by STAE in secret, a surprising amount can be discovered by using available information. Details of the PVT and results from polling stations are available, and CDEs, CPEs, the CNE and the CC all publish results which can be compared.

Comparisons make it possible to pinpoint secret actions. For example, in 2009 more than 104000 votes were excluded by the CNE, apparently from

7 It was published first by AWEPA (European Parliamentarians for Africa) and more recently by a Mozambican CSO, CIP (Centro de Integridade Público). 
polling stations with a turnout of near $100 \%$, and in response to reports of ballot box stuffing. In Tete, 85693 votes were excluded, $16 \%$ of the total votes. Of these, 74555 were for Frelimo candidate Armando Guebuza. The change in Tete was discovered simply by comparing the results announced by the Tete Provincial Elections Commission (CPE) with those announced for Tete by the CNE. In the Niassa parliamentary contest, the CNE withdrew 11130 votes for Frelimo. That was enough to shift one parliamentary seat to Renamo (MPPB 19 November 2009). No mention of these secret changes was made in any official statement or public document.

And, as noted at the beginning of this article, despite the secrecy, public data make it possible to identify errors and sloppiness. Statistical techniques can be applied and most election data follows a 'normal' or Gaussian distribution. In many provinces in many elections in Mozambique, turnout does indeed follow a Gaussian distribution, except that there is an unexpected group of polling stations with a turnout of over $85 \%$. These are polling stations with ballot box stuffing. Similarly, the percentage of invalid ballot papers in a polling station follows a normal Gaussian curve with a centre at about 3\%. Thus, the group of polling stations with over $7 \%$ invalid votes almost surely have opposition ballot papers improperly invalidated. Revisiting past elections, it is possible to estimate the extent of ballot box stuffing, and to use scatter diagrams to show that the extra votes are almost always for Frelimo (MPPB 26 January 2020; Hanlon \& Fox 2006).

As noted above, detailed election results only become available five years after an election, and a detailed statistical analysis of the first four presidential elections showed the first indications of serious fraud in 2004 and that it became much worse in 2009 (Ahlbäck 2017; Hanlon \& Ahlbäck 2016).

In 2004 data from individual polling stations was temporarily posted on a public computer system that was used to estimate ballot box stuffing in Tete province. In the parliamentary election it is estimated that there were 95000 extra 'stuffed' ballots for Frelimo, enough to take two national parliament seats away from Renamo (MPPB 29 December 2004).

Unexpectedly, even in polling stations being observed, polling station staff stuff extra ballot papers or invalidate opposition ballot papers and thus it is possible to use the PVT to estimate fraud. It 2009 it was estimated that $6 \%$ of polling stations had a significant number of intentionally spoiled opposition ballot papers. In addition, $3 \%$ of polling stations had significant ballot box stuffing, but some of these were excluded, in secret, by the CNE. It was estimated that there were 148000 extra, stuffed ballots, and 48000 improperly invalidated $-6.5 \%$ of the total vote of victorious candidate Armando Guebuza (MPPB 19 November 2009; Hanlon 2011). In the 2014 elections there were problems and probable misconduct or fraud in $12.4 \%$ of polling stations. In the presidential election, it 
was estimated that there were 107000 extra, stuffed votes for victorious candidate Filipe Nyusi, and 30000 taken from the opposition by fraudulently spoiling ballot papers (MPPB 28 November 2014; Hanlon 2015). There was a sharp increase in misconduct in the 2019 presidential election. Using PVT data, it was estimated that there were 148000 stuffed ballots for Nyusi and 110000 votes_taken improperly from opposition presidential candidates $-5.6 \%$ of Nyusi's total vote (MPPB 26 January 2020). These figures are necessarily underestimates because these statistical techniques can identify only gross violations. There is also substantial evidence from observers and journalists of widespread, small-scale misconduct in polling stations which appeared otherwise normal, with a few stuffed or falsely invalidated ballot papers.

\section{ACTIVE AND NEUTRAL JUDGES}

The courts are the other outside force which should guarantee the integrity of elections. The various iterations of the electoral law have set up complex procedures which make it virtually impossible to protest. However, the highest electoral court is the Constitutional Council (CC, Conselho Constitucional), which has no public rules of procedure and is free to intervene.

This was shown after the 2013 municipal elections. The CC rejected the appeal by MDM over Gurué municipal elections because it was made too late, but in an unprecedented action went on to carry out its own investigation and found 'flagrant violations of the law by members of polling stations as well as by the Provincial Election Commission of Zambézia'. It cancelled the election and ordered a rerun. The CPE and CNE had declared a Frelimo victory but a parallel count showed an MDM win. First the CC called for a recount, only to find the ballot papers missing. Further investigation showed polling station results sheets replaced by new ones or altered, and two even written by the Zambézia provincial elections commission, not the polling station president (Conselho Constitucional Acórdão $\mathrm{n}^{\circ}$ 4/CC/2014, de 22 de Janeiro). The election was re-run on 8 February 2014 and MDM won with 55\% of the vote.

However, in Mozambique as in many other countries, many magistrates, judges and even $\mathrm{CC}$ members are nominated by the party in power. The activist CC judges had retired, and in 2019 the CC chose not to investigate or intervene.

\section{FLAUNTING THE END OF INTEGRITY}

Integrity is defined as honesty, rectitude, and incorruptibility, and is central to free and fair elections. Integrity had been deteriorating in previous elections in Mozambique, but the 2018-9 elections were notable because of the way the 
ruling party Frelimo flaunted its power. It brazenly changed the results to give it four extra victories in the 2018 municipal elections, and in the 2019 national election inflated the electoral register with 329430 ghost voters, and blocked civil society observation.

What was most striking is that Frelimo publicised rather than hid what it was doing. Two senior and highly respected officials in the National Statistics Institute were not just dismissed for challenging the registration of ghost voters in Gaza, but were public humiliated by President Filipe Nyusi. The CNE brazenly limited the national tabulation assembly to STAE presenting a set of PowerPoint slides, and invited the press to the show. And the Gaza head of CSO observation, Anastácio Matavel, was gunned down in the street, in broad daylight. In previous elections there was some attempt to hide misconduct, whereas in 2019 Frelimo's power to control the elections was blatantly displayed.

Equally notable was the widespread failure of opposition parties to use their deputies in the parliament to dispute changes to the electoral law, and their members of elections commissions and hundreds of appointed people in STAEs to expose the growing misconduct during the elections. It was left to press, observers, and academic researchers to expose the gross frauds in municipal elections, registration, and observer credentials.

Before his death on 3 May 2018, Renamo head Afonso Dhlakama used his remaining military power to push for changes in the electoral laws that deepened the partyization of the electoral process. This in turn deepened the control of the ruling party and ensured Renamo could never become the ruling party. The opposition cannot win at this game.

In 2019 the arrogance of power was on show. This begs several questions:

- whether the imbalance of power means it is now too late to create an electoral process with integrity;

- whether the middle class is so dependent on party patronage that there is no one left who can afford to be independent;

- whether there are enough honest, competent and independent people left who could fill smaller elections commissions and key posts in STAE, and who would be willing to risk being barred from future jobs for not having obeyed a party instruction;

- whether civil society, the opposition, and honourable people in Frelimo could come together to rethink the electoral process;

- whether it would be possible to follow the South African model and have open, public hearings to appoint elections commission members; and finally, 
- whether the elections commissions and STAEs would be prepared to work with total transparency, with all meetings and documents open and accessible.

This depends on whether there are enough Mozambicans ready to demand electoral integrity, or whether it is too late.

\section{Acknowledgement}

This paper is an updated and revised version of a chapter entitled 'Integridade eleitoral em Moçambique: Uma perspectiva política e histórica' in Por um modelo alternativo e funcional de gestão eleitoral em Moçambique, by D do Rasario, E Guambe \& E de Salema, Policy Brief No. 3, EISA, Maputo.

\section{- REFERENCES ——}

Ahlbäck, J 2017, 'How to Cheat: Local-Level Party Dominance and Strategies of Election Fraud', London School of Economics Department of Government Working Paper, 26 November (draft) https://drive.google.com/file/d/19led6yganPq6qS $1 \mathrm{MvlI} 1 \mathrm{~m} 0 \mathrm{LPaUd} 46 \mathrm{qlV} /$ view? $\mathrm{usp}=$ sharing

Annan, K\& Global Commission on Elections, Democracy \& Security 2012, Deepening Democracy: A Strategy for Improving the Integrity of Elections Worldwide, IDEA, Stockholm. https://www.idea.int/publications/catalogue/deepeningdemocracy-strategy-improving-integrity-elections-worldwide, Accessed 11 February 2021.

Beirão, J 2013, МРPB 26 December.

Carimo, S 2012, Canal de Moçambique, 24 October 2012.

Carter, Jimmy 2004, $M P P B$, Issue 31, 29 December.

Cruz, A, Ferreira, I, Flentø, J \& Tarp, F 2020, 'Synthesis and policy recommendations', in A Cruz, I Ferreira, J Flentø, \& F Tarp (eds) Economic Development \& Institutions - Mozambique at a fork in the road - An Institutional Diagnostic. Presented as a draft at a UNU-Wider webinar 4 November 2020. Chapters available at $<$ https://bit.ly/Wider-Inst $>$ (viewed 28 November 2020)

EISA 2019, 'Electoral Integrity in Africa: Under Imminent Threat?', The Fourteenth Annual EISA Symposium, EISA, Johannesburg. https://www.eisa.org/ symp2019.php Accessed 11 February 2021.

Hanlon, J 1996, Peace without profit, James Currey, Oxford.

Hanlon, J 2011, 'Post-Election Review of the Mozambique General Elections of 2009', 
Background paper for and election observer report, https://drive.google.com/ file/d/1rT4LzACnKe3nBYhzIKQjtr4W4BdttSoR/view?usp=sharing

Hanlon, J 2015, 'Media and Fraud Prevention in Elections in Mozambique - using transparency', London School of Economics International Development Research Seminar, 4 February.

Hanlon, J 2020, 'Por um modelo alternativo e funcional de gestão eleitoral em Moçambique', in D do Rasario, E Guambe \& E de Salema, Policy Brief No. 3, EISA, Maputo.

Hanlon, J \& Ahlbäck, J 2016, 'Fraud at polls: can journalists and statisticians check? The Mozambican experience', London School of Economics LSE Public Lecture 16 March 2016. https://drive.google.com/file/d/1ehV3UnV2phBb0m3zYL9h AnD5svB0Ool5/view?usp=sharing

Hanlon, J \& Fox, S 2006, 'Identifying Fraud in Democratic Elections: A Case Study of the 2004 Mozambican Presidential Elections', London School of Economics, London. http://eprints.lse.ac.uk/41857/

Hanlon, J \& Smart, T 2008, Do Bicycles Equal Development in Mozambique? James Currey, Woodbridge, Suffolk, UK.

Instituto Nacional de Estatística - Censo 2017, 2019, 'Informação transmitida ao STAE e aos órgãos da CHE pelo órgão reitor do sistema estatístico nacional (INE): percentagem de população com 18 anos e mais por província' (Enviados ao STAE no dia 25 de Maio de 2019).

Manning, C 2010, 'Mozambique's slide into one-party rule', Journal of Democracy, vol. 21, no 2. pp. 151-165.

Mazula, B 1998, Moçambique: Dados Estatísticos do processo Eleitoral 1994, STAE, Maputo.

Mazua, B 2004, MPPB, 29 December.

Mozambique Political Process Bulletin (MPРB) 1993-. Available at http://www.open. ac.uk/technology/mozambique/mozambique-political-process-bulletin

Mozambique News Reports and Clippings (MNRC) 2007- . Available at http://www. open.ac.uk/technology/mozambique/news-reports-clippings

Norris, P 2015, 'The new research agenda studying electoral integrity', Electoral Studies, vol. 32, no. 4, pp. 563-575. http://dx.doi.org/10.1016/j.electstud.2013.07.015 Accessed 11 February 2021.

Nuvunga, A \& Hanlon, J 2018, 'Local media observation of Mozambique's elections', Journal of African Elections, vol 17, no. 1, pp. 72-92. 